\title{
ISLAM DALAM PERJUANGAN BAGUS RANGIN MELAWAN PEMERINTAH KOLONIAL BELANDA-PRANCIS DAN INGGRIS, 1810- 1812
}

\author{
Tendi \\ Pascasarjana Universitas Indonesia
}

\begin{abstract}
Abstrak
Dua dekade awal abad kesembilan belas, menjadi waktu terjadinya beberapa gerakan sosial di wilayah Karesidenan Cirebon. Pelbagai kerusuhan dan gerakan yang sebab musababnya berkisar tentang keadilan dan ekonomi membuat Cirebon menjadi daerah yang tidak pernah tenang. Ada sejumlah pendapat yang menunjukkan bahwa pihakpihak yang terlibat dalam gerakan ini terdiri dari banyak kelompok dan golongan. Artikel ini mencoba untuk mengungkapkan background sosio-ekonomi masyarakat Cirebon pada awal abad kesembilan belas, dan menguraikan gerakan perjuangan yang digalang oleh Bagus Rangin untuk melawan pemerintahan kolonial pada tahun 18101812. Selain itu, tulisan ini juga berupaya untuk melihat Islam yang tampak dalam gerakan sosial Bagus Rangin tersebut. Metodologi yang digunakan dalam studi ini adalah metode sejarah dengan pendekatan naratif. Hasil dari riset ini adalah kondisi masyarakat Cirebon yang terbelenggu masalah ekonomi akibat adanya kebijakan politik dan pertanahan yang datang dari Batavia. Adapun gerakan yang dipimpin oleh Bagus Rangin merupakan gerakan sosial yang menjadi respon atas kebijakan tersebut. Sedangkan untuk unsur Islam dalam gerakan itu, tampak jelas terlihat dalam sejumlah hal, seperti keyakinan eskatologis, melakukan ziarah, penggunaan pakaian, dan lain sebagainya.
\end{abstract}

Kata kunci: Gerakan Sosial, Pertanahan, Bagus Rangin, Pemerintah Kolonial, Cirebon.

\section{Pendahuluan}

Pada penghujung abad ke-18, VOC (Verenigde Oost-Indische Compagnie) mengalami kebangkrutan dan dinyatakan pailit sehingga ditutup untuk selamanya. $\mathrm{VOC}^{1}$, perusahaan dagang yang telah banyak memberi keuntungan kepada tanah Belanda melalui usaha monopoli dan ekspor-impor komoditas penting sejak hampir 2 abad sebelumnya itu, dengan resmi dinyatakan dibubarkan. Kondisi merugikan itu dapat terjadi akibat adanya penyelewengan oleh para petinggi perusahaan dalam

1 VOC (Verenigde Oost-Indische Compagnie) merupakan suatu badan usaha yang dibentuk pada tahun 1602 guna menghilangkan persaingan yang merugikan antar orang Belanda karena saling berkompetisi memperebutkan komoditi dagang yang laku di pasaran Eropa di daerah-daerah penghasilnya. M. C. Ricklefs, Sejarah Indonesia Modern 1200-2004, (Jakarta: Serambi, 2010), hal. 70-71. 
pengelolaannya. Untuk menutupi segala kerugian yang ada, kemudian seluruh aset kekayaan yang dimiliki oleh VOC diambil alih oleh Pemerintahan Belanda yang juga menjadi pihak yang bertanggung jawab atas segala tanggungan yang dimiliki oleh perusahaan dagang tersebut.

Salah satu aset yang sebelumnya dimiliki oleh perusahaan dagang itu adalah wilayah kekuasaannya yang ada di sejumlah titik Kepulauan Nusantara. Sebagai salah satu wilayah yang sebelumnya dikuasai oleh VOC, Kesultanan Cirebon pun secara otomatis beralih penguasaannya, dari yang semula berada di bawah kekuasaan Kompeni yang selanjutnya menjadi dikuasai Pemerintah Kolonial Belanda. Sejak saat itu, mau tidak mau, Kesultanan Cirebon mesti menuruti segala apa yang digariskan oleh pemerintah kolonial, termasuk dalam tata aturan pengelolaan tanah atau lahan. Penguasaan lahan yang sebelumnya bersifat tunggal di tangan raja atau sultan sebagai perwakilan Tuhan di muka bumi pun turut berganti karena penguasa yang baru lebih menginginkan keuntungan ekonomi.

Persoalan agraria ini telah dijalankan sejak pendahulu pemerintah kolonial Hindia Belanda berkuasa, VOC, berkuasa. Perusahaan dagang itu telah melakukan kebijakan yang radikal dalam masalah agraria dengan melakukan penjualan tanah dan persewaan desa kepada pihak-pihak tertentu demi keuntungan materil semata. Tanah-tanah yang dijual secara bebas oleh Kompenti kepada pihak swasta itu kemudian disebut sebagai tanah partikelir (particuliere landerijen) atau tanah swasta milik perorangan. ${ }^{2}$ Penjualan itu dapat dikatakan sebagai hal yang radikal karena penguasaan yang diberikan atas kompensasi uang yang diberikan terhadap Kompeni tidak hanya terbatas pada hak atas tanah, akan tetapi juga termasuk terhadap hak istimewa untuk melakukan pengelolaan tanah miliknya secara mandiri. Dengan demikian, pemilik tanah yang didapat dari VOC itu tidak jauh berbeda perannya dengan seorang raja kecil karena memiliki hak untuk melakukan kegiatan administratif, hak untuk melakukan pemungutan pajak dan iuran, serta hak

\footnotetext{
2 Kartodirdjo mengungkapkan bahwa tanah partikelir itu ada di Nusantara sejak diperjualbelikan oleh VOC dari awal masa kekuasaan VOC hingga kuarter pertama abad ke-19 di era pemerintahan kolonial Belanda dan Inggris. Menurutnya, "the particuliere landerijen came into existance as result of land sales by the Dutch which had taken place at various times from the early days of the East India Company down to the first quarter of the nineteenth century." Lihat, Sartono Kartodirdjo, Protest Movement in Rural Java: A Study of Agrarian Unrest in the Nineteenth and Early Twentieth Centuries, (Oxford: Oxford University Press and Institute of Southeast Asian Studies, 1973), hlm. 21-22.
} 
untuk melakukan pengaturan terhadap penduduk yang berada di dalam teritorial wilayahnya secara mutlak. ${ }^{3}$

Semula, penjualan tanah hanya terjadi di sekitar wilayah Batavia yang umumnya disebut sebagai wilayah Ommelanden. Daerah ini menjadi surga bagi para pemilik tanah yang sebagian besar adalah orang-orang berkebangsaan Belanda dan Cina. Meskipun secara formal kedaulatan atas wilayah itu berada di tangan para petinggi VOC di Batavia, namun dalam praktiknya, tanah-tanah itu tidak lebih dari tanah-tanah milik pribadi yang secara mutlak dikuasai oleh tuan-tuan tanah beserta oknum-oknum pejabat semata. ${ }^{4}$ Selain yang ada di daerah pedalaman antara Batavia dan Bogor, tanah Partikelir juga hadir kemudian di wilayah Banten, Krawang (Karawang), Tjirebon (Cirebon), Semarang dan Surabaja (Surabaya). Tuan-tuan tanah yang diberi hak milik atas tanah itu memiliki tanggung jawab untuk menjaga rush en orde (tertib dan damai - yang selanjutnya dimaknai sebagai ketertiban dan kedamaian) di wilayah yang mereka kuasai. ${ }^{5}$

Secara umum, para pemilik tanah partikelir jarang sekali memerhatikan kesejahteraan para pekerja dan penduduk yang tinggal di tanahnya. Mereka lebih memerhatikan nilai nominal yang harus mereka dapatkan ketimbang nasib dan kehidupan penduduk. Dengan orientasi keuntungan semacam itu, rakyat kecil yang menempati tanah partikelir diharuskan untuk terus giat bekerja mengolah lahan yang ditugaskan kepada mereka. Tidak ada toleransi yang berarti karena hak atas mereka bersifat absolut. Tidak mengherankan apabila kemudian timbul kantongkantong masyarakat yang penuh derita di tengah wilayah tanah-tanah partikelir. Kondisi rakyat yang hidup disana benar-benar memprihatinkan. Nasib yang tidak jauh berbeda juga dirasakan oleh penduduk yang tinggal di tanah partikelir milik orang-orang Tionghoa yang ada di wilayah Cirebon. ${ }^{6}$ Masyarakat hidup sengsara

\footnotetext{
3 Selo Soemardjan, "Land Reform di Indonesia", dalam Sediono M.P. Tjondronegoro dan Gunawan Winardi (peny.), Dua Abad Penguasaan Tanah, Pola Penguasaan Tanah Pertanian di Jawa dari Masa ke Masa, (Jakarta: Penerbit Yayasan Obor Indonesia/PT. Gramedia, 1984), hlm. 105.

4 Peter Boomgaard, Anak Jajahan Belanda: Sejarah Sosial dan Ekonomi Jawa 1795-1880, terjemahan, (Jakarta: Djambatan, 2004), hlm. 21.

5 Sartono Kartodirdjo, Protest Movement in Rural Java ...., hlm. 21-22.

6 Kepercayaan yang tumbuh kepada etnis ini didasari oleh etos kerja mereka yang baik dan kepuasan VOC atas apa yang bisa mereka dapatkan ketika berhasil memberi kekuasaan lokal dan pengelolaan imigran kepada etnis Tionghoa. Bernard Hubertus Maria Vlekke, Nusantara: A History of Indonesia, (Den Haag: W. Van Hoeve, 1959), hlm. 222.
}

Tamaddun Vol. 6 , No. 2, Juli - Desember 2018 
karena tanah yang mereka tinggali merupakan sumber penghasil penting bagi para tuan tanah dan Kompeni.

Para elit lokal yang terdiri dari para sultan keturunan Panembahan Girilaya yang menjadi pemimpin Kesultanan Cirebon, tidak dapat berbuat banyak untuk menolong rakyat yang sebetulnya menggantungkan harapan dan keselamatan hidup mereka terhadap para penguasa keraton. Hal itu dapat terjadi karena penetrasi orang-orang asing (penguasa kolonial) telah merasuk hingga ke balik tembok istana dan memengaruhi setiap tindak tanduk orang-orang di dalamnya. Dengan kondisi demikian, rakyat semakin merasa kebingungan dengan penderitaan yang mereka rasakan karena tidak mendapat perhatian sebagaimana semestinya dari para penguasa. Di tengah kekalutan itu, rakyat malah menyaksikan bagaimana penguasa kolonial dan para elit mereka mengistimewakan orang-orang Tionghoa kaya yang memiliki tanah luas. Dengan kondisi demikian, tidak mengherankan apabila kemudian rasa tidak suka dan kemarahan rakyat pada saat melakukan gerakan sosial ditujukan kepada para pejabat kolonial, para sultan, dan juga orang-orang Tionghoa. $^{7}$

Tidak adanya institusi khusus yang menangani permasalahan ini, sejak masa pemerintahan Kompeni yang berlanjut hingga masa pemerintahan kolonial, membuat pihak-pihak yang merasa terbebani dengan kondisi memprihatinkan tersebut bereaksi dengan cara yang radikal. Rasa tidak puas dan kecewa pun selanjutnya dimanifestasikan dalam bentuk gerakan sosial dan perlawanan terhadap pihak-pihak terkait. Salah satu gerakan perlawanan yang muncul pada awal abad ke-19 di wilayah Cirebon adalah gerakan Bagus Rangin, yang berpusat di sekitar Jatitujuh Majalengka namun berpengaruh hingga ke Cirebon, Kuningan, Indramayu, Sumedang, Subang, dan Karawang. Sebagai seorang tokoh lokal, tentunya sosok Bagus Rangin termasuk istimewa karena pengaruhnya dapat melewati batas-batas teritorial yang luas. Gerakan perlawanannya pun terbilang merepotkan karena apa yang digalang Bagus Rangin itu dapat membuat beberapa penguasa lokal turun tangan secara langsung, bahkan hingga memerlukan bantuan dari tangan-tangan penguasa lokal dari daerah lain dan juga bantuan pasukan militer terlatih dari pemerintahan pusat Batavia. Apa yang dicapai Bagus Rangin itu didasari oleh karismanya yang kuat, yang dibangun dengan modal-modal nilai keagamaan dan kepercayaan.

7 Demetrius Charles Boulger, The Life of Sir Stamford Raffles, (London: Horace Marshall \& Son, 1897), hlm. 114-115. 
Artikel ini berusaha mengungkapkan latar belakang terjadinya keresahan di wilayah Cirebon pada awal abad ke-19 dan menjelaskan gerakan perlawanan yang digalang oleh Bagus Rangin untuk melawan pemerintahan kolonial. Selain itu, tulisan ini juga berupaya untuk melihat sisi-sisi yang bermuatan nilai-nilai Islam dalam gerakan sosial Bagus Rangin yang menuntut keadilan kepada pemerintah kolonial dalam kurun waktu 1810-1812.

\section{Kondisi Sosial dan Ekonomi Masyarakat Karesidenan Cirebon}

Pada awal abad ke-19, pemerintah kolonial baru saja mengambil alih segala aset yang dimiliki oleh Perusahaan Dagang Hindia Timur (VOC). Kebangkrutan yang dialami oleh badan ekonomi tersebut selanjutnya membuat mereka mengharuskan melepaskan seluruh kekayaan perusahaan terhadap pemerintah kolonial yang menjadi penanggung jawab atas hutang mereka. Transisi kekuasaan itu memengaruhi kondisi yang ada di tanah Hindia karena pelbagai perubahan menuntut adanya penyesuaian-penyusuaian tertentu dalam sistem pemerintahan. Terlebih sejak akhir abad ke-18, negeri Belanda telah dipengaruhi oleh Perancis sehingga pemerintah kolonial yang ada di Nusantara pun orientasinya ikut berubah.

Struktur sosial yang telah ada sejak beberapa masa sebelumnya dapat bertahan hingga ke masa pemerintahan kolonial ini. Struktur masyarakat Cirebon saat itu, masih terbagi menjadi tiga golongan, yaitu golongan atas, golongan menengah, dan golongan bawah. Golongan atas merupakan kaum bangsawan yang terdiri dari pejabat di kalangan birokrasi dan elit agama, sedangkan golongan menengah merupakan pegawai kerajaan yang posisinya tidak terlalu strategis dalam pemerintahan, dan adapun golongan bawah adalah kalangan rakyat biasa yang tersebar di desa-desa. ${ }^{8}$ Tiga kelompok masyarakat Cirebon ini hidup secara berdampingan dan mereka memiliki fungsi masing-masing di dalam proses perjalanan masyarakat wilayah ini. Ketika salah satu kelompok tidak menjalankan fungsinya dengan baik, maka akan muncul masalah dan ketidakseimbangan dalam sistem sosial masyarakat. Masalah yang semula berkembang dalam satu kalangan

${ }^{8}$ Supratikno Rahardjo (ed.), Kota Dagang Cirebon sebagai Bandar Jalur Sutra, (Jakarta : Proyek Inventarisasi dan Dokumentasi Sejarah Nasional, Direktorat Sejarah dan Nilai Tradisional, Direktorat Jenderal Kebudayaan, Departemen Pendidikan dan Kebudayaan RI, 1998), hlm. 40-45. 
itu, bisa memengaruhi kelompok-kelompok lainnya jika tidak ditangani dengan baik.

Kekacauan yang terjadi di wilayah Karesidenan Cirebon pada dua windu awal abad kesembilan belas juga diyakini oleh van Der Kemp sebagai hasil dari ketidakseimbangan yang ada dalam kelompok atas dalam menjalani perannya sebagai pemimpin. Menurutnya, jumlah bangsawan yang sangat besar, ditambah dengan etos kerja mereka yang tidak giat, membuat rakyat semakin sengsara karena bagaimanapun kelompok elit ini dapat bertahan hidup dengan jerih payah yang dilakukan oleh kelompok masyarakat paling bawah tersebut. ${ }^{9}$ Penderitaan itu bisa terjadi karena rakyat terhubung dalam ikatan patron-client dengan para kelompok bangsawan. Dari hubungan ini, rakyat mengharapkan perlindungan, keamanan, kenyamanan kehidupannya di dunia, dan bahkan keberkahan dalam menjalani segala aktivitas, karena para kelompok aristokrat diyakini sebagai perwakilan Tuhan di muka bumi. Sebagai imbalan atas harapan itu, maka mereka rela melakukan apa pun yang diperintahkan tanpa mengharapkan imbalan apapun.

Hubungan kawula-gusti yang mengikat antara rakyat jelata dengan para elit bangsawan seperti ini merupakan kebiasaan lama yang terus dipelihara dari waktu ke waktu. Sejak masa Hindu, hubungan semacam ini terus berjalan, bahkan ketika Islam sudah masuk ke Pulau Jawa. Para penguasa VOC dan pemerintah kolonial, juga turut mempertahankan sistem ikatan ini karena mereka melihat efektivitas dan efisiensi yang ditampilkannya. Dengan iming-iming kekuasaan, kelanggengan, dan ketenangan selama memimpin, para pemimpin lokal ini dipergunakan sebagai kakitangan kekuasaan kolonial. Mereka dibebaskan menjalankan kekuasaan di wilayah yang diembankan kepadanya sesuai kehendak mereka, asal kepentingan VOC dan (selanjutnya) pemerintah kolonial terpenuhi. Singkatnya, melalui kerjasama yang dibangun dengan para elit, penguasa asing dapat memperoleh keuntungan yang berlimpah ruah tanpa sedikitpun mengeluarkan keringat.

Kondisi ekonomi masyarakat Cirebon saat itu dikuasai oleh segelintir orang yang berasal dari kalangan atas. Kelompok ini adalah penguasa kolonial, para bangsawan tingkat tertinggi, dan pedagang-pedagang asing yang memiliki kerjasama baik dengan dua kelompok tadi. Sebagai kota pelabuhan, Cirebon merupakan gerbang bagi bidang perniagaan yang besar. Terlebih posisinya yang terletak di pesisir pantai utara, sangat mendukung eksistensi wilayah ini dalam titik

9 P.H. van Der Kemp, Pemberontakan Cirebon tahun 1818, (Jakarta: Yayasan Idayu, 1979), hlm. 5. 
pelayaran dan perdagangan Nusantara. Dalam studi perbandingan yang dilakukannya, Zuhdi menguraikan bahwa wilayah Cirebon merupakan salah satu tempat dengan potensi alam yang mumpuni untuk dapat terlibat dalam perdagangan dunia. Wilayah yang terdiri dari daerah pedalaman dan pesisir ini kaya pelbagai macam hasil alam, mulai dari kayu berkualitas baik hingga beras yang menjadi makanan pokok masyarakat. ${ }^{10}$ Dataran tinggi yang menjadi bagian Cirebon memang terdiri dari gunung-gunung tinggi yang memiliki hasil kayu yang sangat baik, khususnya kayu jati. Kayu jati daerah ini menjadi primadona di dalam dunia perdagangan karena dapat dimanfaatkan untuk banyak hal, seperti pembuatan perahu, bangunan, dan lain-lain. Jejak komoditas kayu jati di daerah Cirebon masih dapat terlihat hingga saat ini, selain dengan melihat banyaknya tumbuhan itu berkembang di daerah ini yaitu dengan memperhatikan banyaknya nama satuan tempat tinggal yang mengidentifikasikannya ke kayu tersebut, seperti Linggajati, Jatitujuh, Pasir Jati, Gunung Jati, dan lain sebagainya. Di samping itu, dataran tinggi yang dimiliki Cirebon merupakan lahan yang subur bagi kegiatan perkebunan dan tanaman, dan hasil-hasil produksi yang demikian ini adalah komoditas yang bisa diperdagangkan di kota pelabuhan.

Sementara itu, dataran rendah Cirebon menjadi sumber bagi bahan atau makanan pokok kebanyakan masyarakat karena disana tanaman padi dapat dipanen dari sawah-sawah yang kaya akan air. Padi yang kemudian diolah menjadi beras dan untuk selanjutnya dimasak menjadi nasi, merupakan salah satu makanan pokok masyarakat Indonesia yang telah diperdagangkan sejak lama. Indramayu dan Majalengka, merupakan dua daerah yang banyak dikembangkan sebagai sumber penghasil padi bagi Cirebon. Di samping itu, hasil garam juga menjadi primadona bagi daerah pesisir. Bagaimanapun, garam merupakan bumbu makanan terpenting yang banyak dicari karena merupakan penyedap rasa yang paling dibutuhkan dalam membuat masakan yang akan dikonsumsi. Kedua komoditas itu menjadi primadona hasil produksi yang dihasilkan oleh dataran rendah tersebut.

Pelabuhan Cirebon menjadi tempat bertemunya komoditas-komoditas yang berasal dari daerah pedalaman dan pesisir, karena pelabuhan merupakan tempat penampungan surplus hasil bumi dari wilayah pedalaman sehingga selanjutnya bisa

10 Susanto Zuhdi, "Hubungan Pelabuhan Cirebon dengan Daerah Pedalaman: Suatu Kajian dalam Kerangka Perbandingan dengan Pelabuhan Cilacap 1880-1940" dalam Susanto Zuhdi (ed.), Cirebon sebagai Bandar Jalur Sutra: Kumpulan Makalah Diskusi Ilmiah, (Jakarta: Proyek Inventarisasi dan Dokumentasi Sejarah Nasional, Departemen Pendidikan dan Kebudayaan, 1996), hlm. 90. 
didistribusikan ke daerah-daerah lain untuk dimanfaatkan sebagaimana mestinya. Sebaliknya, Cirebon juga menjadi tempat kedatangan pelbagai macam barang lain dari luar untuk kemudian bisa dimanfaatkan di seluruh bagian wilayah pedalaman. Hubungan simbiosis mutualisme itu membuat dua daerah, yaitu pedalaman dan pesisir, menjadi daerah yang saling membutuhkan satu sama lain. Oleh sebab itu, tampaknya sulit untuk bisa berbicara mengenai daerah pedalaman tanpa membahas daerah pesisir dan begitupun sebaliknya. ${ }^{11}$

Hubungan antara dua wilayah tersebut tidak berjalan begitu saja, perlu ide atau pikiran dan tenaga tertentu yang bisa memungkinkannya dapat terjadi. Pikiran itu dibutuhkan untuk mencari jalan yang paling baik agar komoditas itu bisa bertukar posisi untuk kemudian diperdagangkan dan tenaga dibutuhkan untuk menjalankan ide atau pikiran tersebut. Orang-orang yang kemudian dapat menempati posisi sebagai pemikir untuk menghubungkan dua daerah ini pada masa kolonial adalah orang-orang Tionghoa yang ada di wilayah Cirebon. Memang ada dari kelompok lain yang juga turut berkecimpung dalam bisnis ini, akan tetapi jumlahnya tidak sebanyak dari kalangan Tionghoa.

Pihak-pihak yang menjadi mediator atau broker ini merupakan tengkulaktengkulak besar yang dalam perkembangan selanjutnya menjadi sangat menentukan, bahkan melebihi peran dari para petani itu sendiri. Dalam peranannya ini, orang yang berperan sebagai mediator memiliki akses strategis terhadap bidang jasa dan perdagangan. Selain pihak pemerintah dan kelompok bangsawan, pihak yang bisa memasuki area ini adalah para pedagang-pedagang asing yang sebagian besarnya adalah orang Tionghoa. Kelompok petani tidak dapat berbuat banyak karena mereka telah diikat oleh beban hutang produksi yang sebelumnya ditawarkan secara cerdik oleh para tengkulak. Oleh karena itu, ketika musim panen tiba, yang menerima hasil atau keuntungan paling besar bukanlah para petani, melainkan para tengkulak yang dapat memanfaatkan posisi tawar mereka sebelumnya. Hal itu selanjutnya membuat kehidupan petani tetap menderita dan membuat para tengkulak menjadi semakin sejahtera. Fenomena itu memang tidak dapat dikatakan sebagai suatu hal yang adil, namun kenyataan yang ada di lapangan seperti itu dan bahkan terus berjalan hingga era modern sekarang ini.

Kondisi sosial yang penuh dengan ketimpangan dan perilaku-perilaku yang non-humanis, dibarengi dengan kondisi ekonomi yang sangat kapitalis, membuat situasi di Cirebon menjadi sangat rentan akan konflik. Ketidakadilan yang berkembang menjadi keresahan, pada titik-titik tertentu dapat berubah menjadi

${ }^{11}$ Supratikno Rahardjo (ed.), Kota Dagang Cirebon ...., hlm. 54-56. 
kerusuhan dan itu sangat membahayakan posisi penguasa. Karena tidak pernah ada perbaikan yang benar-benar memuaskan masyarakat, maka di Cirebon selalu resah dan rusuh.

Seolah sepakat dengan kondisi sosial dan ekonomi sebagai penyebab kerentanan Cirebon akan konflik, Stevens (1978: 79) pernah mengungkapkan bahwa rawannya daerah Cirebon terjerumus ke dalam gejolak disebabkan oleh faktor-faktor yang ia rangkum ke dalam tujuh elemen, yaitu:

(1) Keinginan untuk melakukan restorasi atau pengembalian kekuasaan yang seyogyanya dimiliki oleh para sultan Cirebon, karena sebelumnya telah ada pemangkasan secara gradual oleh pemimpin kolonial hingga mereka hanya berposisi sebagai pemimpin adat semata;

(2) Adanya rivalitas di antara para pangeran Cirebon, yang saat itu terjadi antara Pangeran Raja Kanoman, putra mahkota yang tidak jadi menjabat sebagai Sultan Anom menggantikan ayahnya karena kehilangan pulung keraton pada 1797, dengan dua sultan yang saat itu sedang menjabat, yaitu Sultan Sepuh VII dan Sultan Anom V;

(3) Upaya perlawanan terhadap penetrasi ekonomi orang-orang Cina atau Tionghoa. Kiprah para pendatang etnis Tionghoa yang bergerak dalam bidang ekonomi dengan berperan sebagai penyewa lahan kepada pihak kolonial, para pangeran, dan pemimpin adat, selanjutnya memberi kesan negatif kepada mereka karena dalam pengelolaannya melakukan tindakan eksploitatif terhadap para petani dan tanah yang disewanya itu;

(4) Permintaan kompeni beserta para penjajah asing berikutnya yang berlebihan terhadap hasil-hasil produksi yang berasal dari masyarakat atau rakyat;

(5) Perilaku koruptif berbentuk pemerasan dari para pejabat kolonial yang dilakukan secara massif dan hal itu bertentangan dengan masyarakat karena membenani kehidupan mereka; 
(6) Pengenalan sistem pajak tanah yang dilakukan oleh Raffles dan pelbagai penyelewengan yang terjadi dalam pemberlakuannya;

(7) Adanya peningkatan jumlah kepemilikan lahan yang mengatasnamakan pihak swasta Barat. Kepemilikan itu seolah tidak dibatasi karena mereka bisa melakukan perluasan lahan sehingga seorang tuan tanah dapat memiliki lahan yang sangat luas.

Dengan kondisi sosial dan ekonomi yang tumpang tindih sehingga menempatkan kesenjangan yang nyata antara kelompok masyarakat bawah dengan kelompok atas, akhirnya pelbagai kejadian yang menyusahkan aparat keamanan pun terjadi. Bermula dari protes, perlawanan verbal, hingga aksi perlawanan pada akhirnya benar-benar membara di seantero wilayah Cirebon.

\section{Gerakan Perlawanan Bagus Rangin terhadap Pemerintah Kolonial}

Bagus Rangin adalah anak dari Sentayem (Buyut Tayom) yang berasal dari Blandong, Rajagaluh, Majalengka. Ekadjati menyebutkan bahwa daerah Blandong atau Demak Blandong ini berada di wilayah Majalengka yang termasuk ke dalam kawasan di bawah kaki Gunung Ciremai. ${ }^{12}$ Waktu kelahirannya tidak diketahui secara pasti, namun diyakini bahwa kelahiran Bagus Rangin tersebut terjadi pada sekitar tahun 1761. Bagus Rangin bukan anak sulung ataupun bungsu, karena ia memiliki seorang kakak yang bernama Bangin (Buyut Bangin), dan dua adik yang bernama Salimar (Buyut Salimar), dan Bagus Serit. Keluarga Bagus Rangin adalah keluarga yang taat dalam menjalani ajaran Islam karena Sentayem sendiri dikenal sebagai seorang guru ngaji, yang dalam kurun waktu tersebut dapat dikatakan sebagai tokoh paling berpengaruh dalam aspek keagamaan di tengah masyarakat. Pada waktu itu, Sentayem tidak hanya mengajarkan ilmu agamanya kepada anakanak Blandong saja namun juga mengarahkannya kepada anak-anak kandungnya agar mereka memiliki pondasi keagamaan yang kuat. Dengan demikian, Bagus Rangin merupakan seorang pribadi yang telah mengenal dasar pengetahuan dan wawasan mengenai agama Islam sejak ia masih belia.

Penanaman nilai-nilai dasar keagamaan itu dibarengi dengan nilai-nilai kehidupan sehingga kemudian Bagus Rangin memiliki karakter kritis, berani, dan memiliki sifat yang solid terhadap kelompoknya. Rasa berani yang ada dalam diri

12 Lihat lebih lanjut, Edi Suhardi Ekadjati, Sejarah Perlawanan Terhadap Imperialisme dan Kolonialisme di Daerah Jawa Barat, (Jakarta: Perpustakaan Nasional, 1990). 
Bagus Rangin pun terbangun karena sejak kecil sudah diajak oleh ayahnya untuk mengikuti aktivitas yang dilakukannya. Aktivitas sang ayah yang sangat peduli terhadap lingkungan, membuat sang anak terinspirasi untuk selalu peduli dengan orang lain. Kegiatan sosial itu tidak hanya meninggalkan jejak kehidupan yang postitif, namun juga dapat menjadi cerminan bagi sang putra untuk melakukan kebaikan sebagaimana yang dilakukan oleh ayahnya.

Karakter yang dimiliki oleh Bagus Rangin adalah ketegasan dan keberanian. Terkait hal ini, Stapel berani menggambarkan sosok Bagus Rangin sebagai tokoh pemimpin yang gagah dan memiliki keberanian sehingga ia dapat menyatakan perang terhadap penguasa kolonial yang jelas-jelas memiliki kekuatan militer jauh lebih besar. ${ }^{13}$ Dengan sifatnya yang tidak mengenal rasa takut itu, Bagus Rangin senantiasa memberikan inspirasi kepada para petani untuk memiliki keberanian dalam menyuarakan keresahan mereka terhadap penguasa kolonial. Selanjutnya, karakter tegasnya itu dapat menarik banyak kalangan petani yang ditemui Bagus Rangin untuk mengikuti pergerakannya.

Pergerakan yang dilakukan oleh Bagus Rangin bermula ketika ia secara sadar melihat bahwa orang-orang di sekelilingnya yang berprofesi sebagai petani dan penggarap lahan-lahan yang dimiliki oleh para tuan tanah hidup tanpa harapan. Sejak bertahun-tahun sebelumnya, kehidupan mereka seolah tidak berubah karena hanya begitu-begitu saja. Namun di sisi lain, para pemilik tanah dapat hidup dengan sangat menyenangkan. Kesejahteraan mereka terjaga dan kehidupan mereka pun terlihat sangat bahagia. Kesenjangan ekonomi di tengah-tengah masyarakat itu kemudian menjadi bahan renungannya selama beberapa waktu, dan ia banyak bertukar pikiran tentang keresahannya itu dengan kawan-kawannya, para petani, dan guru agamanya. Sebagai hasil kontemplasinya, ia menyatakan bahwa kebobrokan hidup mereka itu disebabkan oleh adanya perilaku yang salah dari para tuan tanah dan pejabat-pejabat pemerintah yang memiliki tanggung jawab atas kehidupan mereka. Oleh karena itu, ia mencoba mencari solusi atas permasalahan yang dihadapinya dengan cara melakukan semedi (meditasi) di tempat-tempat tertentu yang terkenal angker.

Aktivitas ini dilakukan agar Bagus Rangin dapat melakukan pemusatan pikiran dan perasaan, mengheningkan cipta dan memusatkan segenap pikiran agar bisa mendapatkan jawaban atas segala pertanyaan yang berggelayutan di dalam

${ }^{13}$ F.W. Stapel, Geschiedenis van Nederlandsch Indie, Batavia: 1940, Jilid V, h. 24. 
benaknya. Moertono mengungkapkan bahwa aktivitas semacam ini merupakan suatu hal yang lumrah dilakukan oleh tokoh-tokoh yang hendak melakukan perubahan karena ia membutuhkan hal yang dapat menguatkan hati dan tekad. Menurutnya, para pemimpin sebelum memulai usaha revolusionernya akan melakukan pengasingan diri sebagai perwujudan pemikiran magis dan religius. Hal ini sengaja dilakukan karena sang pemimpin mengharapkan sokongan yang bisa memperkuat keinginannya untuk melakukan perlawanan terhadap kekuatan yang akan dihadapinya. ${ }^{14}$ Dengan melakukan semedi, timbul harapan bahwa usaha yang hendak dilakukan akan menemui keberhasilan.

Tempat yang didatangi oleh Bagus Rangin dalam rangka maneges-nya, adalah tempat-tempat yang terkenal sebagai tempat angker dan dapat memberi petunjuk atau keberhasilan. Di tempat pencarian ilham itu, ia melakukan munajat dan memohon kepada Tuhan yang Maha Esa agar apa yang diinginkan oleh diri dan masyarakat yang diperjuangkannya dapat terwujud. Salah satu tempat semedi Bagus Rangin dalam upayanya mencari ketetapan hati dan tekad untuk melakukan perlawanan terhadap pihak kolonial adalah sebuah tempat di Pasir Luhur yang lokasinya merupakan bagian dari wilayah Banyumas. Di daerah yang merupakan batas bagi etnis Sunda dan Jawa ini, Bagus Rangin melakukan semedinya hingga dua kali, dan yang terakhir ia lakukan adalah pada tahun 1811 dalam jangka waktu kurang lebih satu bulan. Dalam semedinya yang kedua ini, para pengikutnya datang menyusul kesana untuk menjemputnya agar ia segera kembali ke Majalengka dan memimpin gerakan perlawanan terhadap pihak kolonial. ${ }^{15}$ Setelah hatinya merasa mantap, akhirnya Bagus Rangin pun pergi dari Pasir Luhur menuju Majalengka. Disana, ia akan melakukan aksi yang akan selalu dikenang oleh masyarakat Cirebon.

Di Majalengka, Bagus Rangin mulai melaksanakan gerakan dengan bantuan para pengikutnya. Ia tidak sulit mendapatkan pengikut di daerah Majalengka, Indramayu, dan Cirebon, karena di daerah itu acapkali terjadi kerusuhan yang berawal dari keresahan petani terhadap masalah agraria yang tidak kunjung selesai. Dengan bergabung bersama Rangin, petani-petani yang kehilangan arah itu seolah merasa menemukan tempat untuk berlindung dan mencari keadilan. Karena adanya unsur prophetic, dan juga keyakinan akan kehadiran sosok ratu adil dalam diri

\footnotetext{
${ }^{14}$ Soemarsaid Moertono, Negara dan Usaha Bina-Negara di Jawa Masa Lalu, Studi tentang Masa Mataram II Abad XVI-XIX, (Jakarta: Yayasan Obor Indonesia, 1985), hlm. 93.

15 R.A.A. Martanagara, Babad Sumedang, edisi Said Raksakusumah dan Edi S. Ekadjati, 1978, hlm. 126-128.
} 
Bagus Rangin maka gerakan ini diidentifikasi sebagai gerakan sosial yang bersifat messianisme dan millenarisme.

Pengaruh Bagus Rangin di tengah masyarakat Majalengka tidak dapat dipandang sebelah mata, karena terbilang sangat besar. Bahkan, ia bisa mendapatkan pengikut yang juga berasal dari daerah-daerah lain. Karismanya itu semakin membuat mata para pengikut Bagus Rangin terkesima dan menganggapnya sebagai Ratu Adil yang bisa membuat mereka bebas dari belenggu penderitaan yang diakibatkan oleh kedzaliman para penguasa dan tuan-tuan tanah partikelir yang ada di wilayah mereka. Di samping itu, Bagus Rangin juga diyakini dapat membawa keadilan dan kemakmuran bagi rakyat. Mereka mempercayai bahwa kepemimpinan Rangin, dalam sebuah negara yang dinamakannya Panca Tengah, adalah kepemimpinan yang diramalkan dan merupakan janji Tuhan yang tengah direalisasikan. Kedua hal ini merupakan unsur-unsur yang kerap hadir dalam gerakan messianisme dan millenarisme di tengah masyarakat.

Deklarasi pembentukan Negara Panca Tengah yang dilakukan oleh Bagus Rangin merupakan gerakan awal yang ia upayakan untuk mewujudkan cita-citanya, yaitu menghapuskan kekuasaan asing yang dzalim dan menggantikannya dengan kekuasaan pribumi yang memiliki nilai-nilai keadilan di tengah masyarakat. Negara Panca Tengah yang dipimpin langsung oleh Bagus Rangin itu berpusat di Bantarjati, wilayah Majalengka sekarang. Pendirian kekuasaan ini bertujuan untuk meringangkan beban derita yang dialami oleh rakyat atas perilaku para tuan tanah yang melebihi batas-batas kemanusiaan, kelompok pejabat yang membebani mereka dengan pajak-pajak yang mencekik, dan para penguasa kolonial yang dianggap telah menghancurkan tatanan tradisional yang ada. Harapan terhadap suatu kondisi ideal yang benar-benar merepresentasikan keadaan masyarakat yang makmur dan sejahtera, menunjukkan bahwa kondisi riil mereka saat itu adalah penuh dengan masalah dan kesengsaraan karena realitas sosial serta ekonomi yang ada tengah membunuh mereka secara pelan-pelan. Untuk itu, Bagus Rangin terus berupaya menggalang kekuatan dan persatuan rakyat yang akan dipimpinnya melawan musuh-musuh mereka.

Dalam usahanya untuk melakukan konsolidasi kekuatan, Bagus Rangin menyatakan dirinya sebagai raja. Di tengah-tengah pengikutnya, ia dinobatkan sebagai Raja dari Negara Panca Tengah. Seseungguhnya, Rangin tidak memiliki keingingan untuk mendeklarasikan diri sebagai seorang raja, namun karena yang ia hadapi adalah raja-raja lokal dan juga gubernur jenderal (yang di tengah 
masyarakat awam dianggap sebagai raja), maka mau tidak mau ia pun perlu melakukan deklarasi itu. Maksud dari penobatan itu, tidak lain adalah guna mendapatkan pengakuan bahwa mereka memiliki posisi yang seimbang dan tidak dapat dianggap remeh oleh musuh-musuhnya. Para penguasa dan elite pribumi yang bersekutu dengan pihak kolonial pun segera melaporkan hal ini, segera setelah mereka mendapatkan berita. ${ }^{16}$ Kenyataan ini kemudian membuat murka pihak kolonial karena menganggap bahwa Bagus Rangin memiliki maksud untuk melakukan tindakan makar karena ia berani menobatkan dirinya sebagai penguasa tanpa persetujuan pihak penguasa Eropa.

Pihak kolonial yang tengah berkuasa pada saat terjadinya gerakan dan penobatan diri Bagus Rangin adalah Inggris, dan pemimpin tertingginya di tanah Jawa adalah Letnan Jenderal Thomas Stamford Raffles. Untuk memadamkan gerakan yang dilakukan oleh Rangin di wilayah Karesidenan Cirebon itu, Raffles membangun kekuatan yang terdiri dari pelbagai macam satuan pasukan yang berasal dari kalangan pribumi dan Eropa. Dari kelompok pribumi, terdapat pasukan yang berasal dari Bupati Cianjur, Pangeran Surianagara, dan Suriadipura dari Mangkunegara, Surialaga dari Karawang dan pasukan Kesultanan Kasepuhan. Sementara itu, dari kelompok Eropa, pasukan yang ada adalah pasukan yang dipimpin oleh Komisaris Couperus.

Setelah kekuatan berhasil dihimpun, Raffles pun memerintahkan para bawahannya untuk bergegas ke Cirebon dan melakukan tindakan penyerangan. Para serdadu pemerintahan kolonial ini pun langsung berangkat dan menuju Cirebon dari tempat masing-masing. Di lokasi, pasukan-pasukan itu berada di bawah koordinasi para pemimpin mereka yang terus melakukan pematangan strategi penyerangan. Hingga kemudian, pada pertengahan Bulan Februari 1812, pasukan gabungan itu melakukan serangan ke basis pertahanan Bagus Rangin dan Negara Panca Tengahnya di Bantarjati, Jatitujuh. Pertarungan dua kekuatan itu berjalan dengan sengit, dan masing-masing pihak tidak ada yang ingin mengalah. Hal itu membuat pertempuran yang terjadi berjalan dengan tempo yang cukup lama, yaitu selama hampir dua minggu, terhitung dari tanggal 16 sampai dengan tanggal 29 Februari 1812.

\footnotetext{
16 Salah satu contoh laporan yang dilakukan oleh penguasa pribumi adalah laporan Raden Dipati Natadireja kepada Gubernur Jenderal Willem H. Daendels. Dalam laporan itu, Natadireja menyimpulkan Bagus Rangin sebagai salah satu tokoh penting bagi terjadinya kerusuhan di wilayah Cirebon dan sekitarnya. Untuk memahami hal ini lebih dalam, lihat lampiran dalam bagian terakhir artikel ini.
} 
Dalam pertempuran ini, pasukan gabungan pemerintah kolonial meraih kemenangan karena jumlah mereka jauh lebih banyak dan disokong dengan peralatan tempur yang lebih modern. Pasukan Bagus Rangin yang mendapati kekuatan lawan seperti itu, sempat melawan dengan sengit hingga beberapa hari, namun akhirnya karena amunisi dan perlengkapan perang mereka tidak selengkap yang dimiliki pihak lawan, akhirnya kekuatan Bagus Rangin dan para pengikutnya pun mengalami kekalahan. Pasukan Bagus Rangin yang telah kalah akibat serangan bertubi-tubi lawan, akhirnya terdesak semakin mundur dan menjadi tercerai berai. Bagus Rangin dan pasukannya pun melarikan diri untuk menyelamatkan nyawa mereka dari sergapan musuh ke Desa Sindang, yang termasuk wilayah Rancabolong. Sementara itu, pasukan yang dipimpin Senan, sejawat Rangin, yang masih melakukan perlawanan di medan lagi harus menelan kekalahan. ${ }^{17}$ Sementara itu, panglima-panglima lain Panca Tengah, seperti Jayakusuma dan Jasa dapat pergi dari medan pertempuran untuk melarikan diri dari kepungan musuh yang datang dari pelbagai penjuru.

Guna menghabisi seluruh kekuatan Bagus Rangin dan membereskan gerakannya, pasukan gabungan itu pun melakukan operasi militer yang terus dilakukan di desa-desa tertentu yang dicurigai sebagai tempat berlindungnya Bagus Rangin. Sebagaimana dilaporkan pejabatnya yang bernama Raden Dipati Natadireja, Rangin dilindungi oleh sejumlah pejabat tingkat bawah yang simpati terhadap gerakannya. ${ }^{18}$ Oleh karena itu, ia sempat dapat beberapa kali menyelamatkan diri dari operasi militer pasukan gabungan. Namun karena operasi itu terus menerus dilakukan dan melibatkan banyak pihak termasuk mata-mata penguasa yang berada di wilayah pedesaan, akhirnya Bagus Rangin dapat ditangkap di daerah Panongan pada tanggal 27 Juni 1812 oleh pasukan gabungan yang berasal dari Bupati Karawang, Surialaga, Tumenggung Raksayuda, dan mantri Kanoman, Raden Jayanagara. ${ }^{19}$

17 Meninggalnya Buyut Sena, menurut Yoseph Iskandar mengejutkan Bagus Rangin dan para pimpinan lainnya. ketika diperiksa, ternyata Buyut Sena ditembak dengan peluru emas. Pasukan Inggris menggunakan sesepuh dari lingkungan Kasepuhan dan Kanoman untuk mengetahui kelemahan pasukan Bagus Rangin. Yoseph Iskandar, Bagus Rangin, (Bandung: Perpustakaan Kebudayaan Sunda Universitas Padjajaran, 1990), hlm. 132-138.

${ }^{18}$ Lihat surat laporan dalam lampiran.

19 Ibid., hlm. 112, Bundel Cirebon, 19/8. 


\section{Islam dalam Gerakan Perjuangan Bagus Rangin}

Gerakan sosial yang dipimpin oleh Bagus Rangin dalam melakukan perlawanan terhadap penguasa kolonial ini bukanlah gerakan sosial biasa, karena ia melibatkan unsur-unsur keagamaan, yang dalam hal ini adalah agama Islam. Bagus Rangin adalah seorang muslim dan para pengikutnya hampir seluruhnya adalah orang Islam, oleh karena itu unsur-unsur yang menunjukan citra Islam begitu kental dalam gerakan yang berpusat di Bantarjati, Jatitujuh, Majalengka ini.

Sejumlah citra Islam yang terlihat dalam gerakan perjuangan Bagus Rangin itu dapat diidentifikasi sebagaimana berikut:

1. Kepercayaan terhadap sosok penyelamat di Akhir Zaman

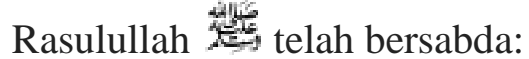

"Pada akhir zaman akan muncul seorang khalifah yang berasal dari umatku, yang akan melimpahkan harta kekayaan selimpah-limpahnya, dan ia sama sekali tidak akan menghitung-hitungnya." (HR. Muslim dan Ahmad)

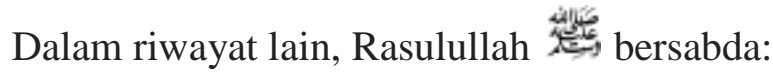

"Sungguh, bumi ini akan dipenuhi oleh kezhaliman dan kesemena-menaan, dan apabila kezhaliman serta kesemena-menaan itu telah penuh, maka Allah SWT akan mengutus seorang laki-laki yang berasal dari umatku, namanya seperti namaku, dan nama bapaknya seperti nama bapakku. Maka ia akan memenuhi bumi dengan keadilan dan kemakmuran, sebagaimana ia (bumi) telah dipenuhi sebelum itu oleh kezhaliman dan kesemena-menaan. Di waktu itu langit tidak akan menahan setetes pun dari tetesan airnya, dan bumi pun tidak akan menahan sedikit pun dari tanaman-tanamannya. Maka ia akan hidup bersama kamu selama 7 tahun, atau 8 tahun, atau 9 tahun." (HR. Thabrani)

Konsep penyelamat yang ada di akhir zaman sebagaimana hadits tersebut merujuk kepada kedatangan sosok Imam Mahdi yang akan menjadi penyelamat dunia dari kedzaliman. Tokoh itu merupakan juru selamat, yang bahkan diyakini pula dalam pelbagai ajaran agama lain selain Islam. Dalam konteks gerakan yang mulai berkobar dari wilayah Majalengka ini, Bagus Rangin pun sempat dipercayai sebagai sosok juru selamat yang dijanjikan. Di mata para pengikutnya di Bantarjati, Rangin diyakini sebagai Ratu Adil, sosok yang digambarkan serupa dengan sosok Imam Mahdi yang akan membawa umat manusia menuju kehidupan yang lebih makmur dan sejahtera.

Dalam Kitab Suci Umat Islam, Al-Qur'an, ada pula ayat yang ditafsirkan sebagai penunjuk menuju sosok dan keberadaan Imam Mahdi. 
Salah satunya adalah firman Allah SWT yang terdapat dalam Surah an-Nûr (24) ayat 56, yang berbunyi:

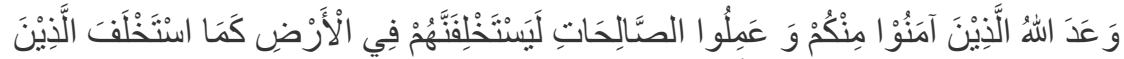

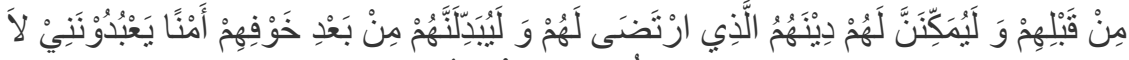

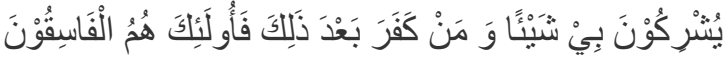

“Allah telah menjanjikan kepada orang-orang yang beriman dan mengerjakan amal salih untuk menjadikan mereka sebagai khalifah di muka bumi ini sebagaimana Ia telah menjadikan orang-orang sebelum mereka sebagai khalifah, menyebarkan bagi mereka agama yang telah diridhainya untuk mereka secara merata dan menggantikan ketakutan mereka dengan rasa keamanan (sehingga) mereka dapat menyembah-Ku dan tidak menyekutukan-Ku. Barangsiapa ingkar setelah itu, merekalah orang-orang yang fasiq."

2. Memanjatkan doa kepada Allah SWT dalam ritual tertentu

Dalam ajaran Islam, dinyatakan bahwa doa adalah senjata Umat Islam. Oleh karena itu, ritual meminta kepada Tuhan ini tidak pernah lepas dari segala aspek kehidupan kaum muslim. Meskipun dalam setiap agama, ritual keagamaan itu ada, namun dalam Islam, doa mesti dipanjatkan hanya kepada Allah SWT. Tidak diperbolehkan untuk meminta kepada yang lain, karena itu akan dianggap sebagai sebuah kemusyrikan. Secara etimologis, kata doa berasal dari kata ista'aana, yang artinya adalah memohon pertolongan Allah. Selain dari asal kata ista'aana, ada juga yang mengatakan bahwa kata doa tidak jauh berbeda dengan kata istighatsah. Konsep doa dengan asal kata ista'aana dan istighatsah tersebut terdapat di dalam Al-Qur'an yang menjadi Kitab Suci Umat Islam. Dalam Surat AlAnfaal, ayat 9, Allah SWT berfirman:

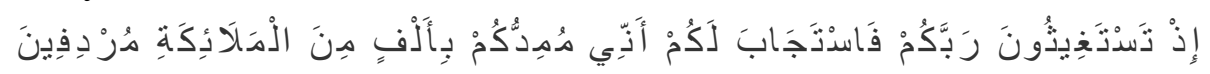

"(Ingatlah), ketika kamu memohon pertolongan kepada Tuhanmu, lalu diperkenankan-Nya bagimu: "Sesungguhnya Aku akan mendatangkan bala bantuan kepada kamu dengan seribu malaikat yang datang berturut-turut."

Ayat ini merupakan penjelasan mengenai pertolongan Allah yang diberikan kepada Nabi Muhammad SAW saat menghadapi kaum kafir dalam medan Perang Badar. Dengan mengutif hadits nabi, Shihab turut 
menguatkan keterangan ini dalam karya tafsirnya. ${ }^{20}$ Ritual meminta doa yang dilakukan oleh Nabi menjadi inspirasi bagi Bagus Rangin untuk melakukan hal yang sama. Terlebih pada saat itu, kondisi yang dialami oleh pasukan Bagus Rangin dirasa memiliki kondisi yang sama dengan pasukan nabi di Perang Badar. Oleh karenanya, Bagus Rangin senantiasa meminta para pengikutnya untuk selalu melakukan munajat kepada Allah SWT, di samping memperkuat fisik mereka dengan keahlian bela diri dan senjata peperangan.

3. Menggunakan atribut berwarna putih saat melakukan gerakan

Sebelum melakukan gerakan, Bagus Rangin mempersiapkan pasukannya dengan gemblengan khusus. Ia membagi pasukannya ke dalam beberapa bagian, dan kemudian memberikan pelatihan kepada mereka. Dalam keterangan penduduk Jatitujuh yang diinterogasi pemerintah kolonial saat itu, pelatihan yang dilakukan oleh Bagus Rangin terhadap anak buahnya dilakukan dengan memakai atribut serba putih dan dilakukan setelah dilaksanakannya shalat jum'at di sebuah masjid di Jatitujuh. Adapun atribut yang serba putih itu, merupakan refleksi atas tanda-tanda kesucian, kebersihan hati, keikhlashan, rela berkorban dengan segala apa yang dimiliki, untuk kepentingan bangsa dan agama. ${ }^{21}$

Memakai atribut putih, memang merupakan suatu amalan sunah yang ada dalam ajaran Islam. Meskipun bukan perkara wajib, namun banyak yang mengikuti anjuran ini karena berharap akan limpahan pahala yang dapat diraih jika mengamalkannya.

Dalam sebuah hadits, diriwayatkan bahwa:

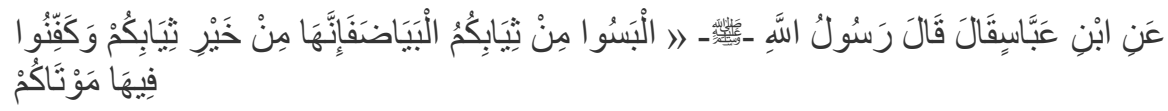

"Dari Ibnu 'Abbas r.a ia berkata, Rasulullah Saw. :"Pakailah oleh kalian dari pakaian-pakaian kalian yang berwarna putih. Karena sesungguhnya pakaian berwarna putih itu adalah pakaian terbaik kalian, dan kafanilah dengannya orang yang meninggal diantara kalian.” (HR. Abu Dawud, at-Tirmidzi,Ahmad bin Hambal, at-Thabrani, Ibnu Hibban, dan 'Abdu Razzaq).

20 M. Quraish Shihab, Tafsir Al-Misbah: Pesan, Kesan, dan Keserasian Al-Qur'an, (Jakarta: Lentera Hati, 2009), cet. Ke-2, Volume V, h. 474-475.

${ }^{21}$ Edi Suhardi Ekadjati, Sejarah Perlawanan Terhadap Imperialisme dan Kolonialisme di Daerah Jawa Barat, (Jakarta: Perpustakaan Nasional, 1990), hlm. 109. 
Dengan adanya hadits tersebut, tidak mengherankan apabila kemudian banyak kalangan Islam yang memakai atribut, baik itu pakaian, celana, hingga asesoris lainnya, yang berwarna putih. Begitu pun juga dengan Bagus Rangin, ia yakin bahwa pakaian putih tidak hanya sematamata warna biasa, melainkan warna yang bisa membawa kemenangan bagi perjuangan mereka untuk menghapuskan kekuasaan asing di tanah yang mereka junjung tinggi.

\section{Kesimpulan}

Kondisi sosial yang penuh ketimpangan dan dibarengi dengan kondisi ekonomi yang memberatkan pada awal abad kesembilan belas, membuat masyarakat di wilayah Karesidenan Cirebon hidup dengan sangat menderita. Kelompok petani menjadi kalangan yang paling terbebani karena mereka dibawah kendali para tuan tanah yang selalu menghisap tenaga mereka untuk kepentingan pribadi semata. Gerakan petani yang menuntut keadilan pada tuan tanah dan pemerintah kolonial merupakan hal yang jamak terjadi pada masa kekuasaan pemerintah Hindia Belanda.

Keadaan yang kacau itu membuat timbulnya keresahan di tengah masyarakat dan tampilnya Bagus Rangin, seorang pemimpin yang digadanggadang sebagai Ratu Adil yang akan mengeluarkan mereka dari nasib buruk kehidupan dunia. Gerakan ini pun kemudian ia rintis dengan membangun kekuatan dan pasukan, serta mendirikan negaranya sendiri yang disebutkan bebas dari pengaruh kekuatan manapun, yaitu Negara Panca Tengah. Sayangnya, eksistensi kelompok Bagus Rangin ini tidak dapat bertahan lama karena kemudian pihak kolonial memerangi mereka dan menghukumnya sesuai dengan hukum yang berlaku.

Dalam pergerakan ini, terlihat adanya sejumlah unsur Islam, antara lain: 1) Adanya pemahaman mengenai konsep mengenai sosok juru selamat pada masa berakhirnya dunia atau menjelang hari-hari akhir (kiamat); 2) Melakukan ritual doa kepada Allah SWT atau Sang Khaliq yang diyakini akan memberikan mereka pertolongan dalam peperangan sebagaimana yang didapatkan nabi dalam Perang Badar di tanah Arab; dan 3) Penggunaan atribut yang bernuansa warna putih pada saat latihan dan aksi perjuangan. 


\section{Daftar Pustaka}

Boomgaard, Peter. 2004. Anak Jajahan Belanda: Sejarah Sosial dan Ekonomi Jawa 1795-1880. Jakarta: PT Djambatan.

Boulger, Demetrius Charles. 1897. The Life of Sir Stamford Raffles. London: Horace Marshall \& Son.

Ekadjati, Edi S. 1990. Sejarah Perlawanan Terhadap Imperialisme dan Kolonialisme di Daerah Jawa Barat. Jakarta: Perpustakaan Nasional.

Iskandar, Yoseph. 1990. Bagus Rangin. Bandung: Perpustakaan Kebudayaan Sunda Universitas Padjajaran.

Kartodirdjo, Sartono. 1973. Protest Movement in Rural Java: A Study of Agrarian Unrest in the Nineteenth and Early Twentieth Centuries. Singapore: Oxford University Press and Institute of Southeast Asian Studies.

Kemp, P.H. van Der. 1979. Pemberontakan Cirebon tahun 1818. Jakarta: Yayasan Idayu.

Martanagara, R.A.A. 1978. Babad Sumedang, edisi Said Raksakusumah dan Edi S. Ekadjati.

Moertono, Soemarsaid. 1985. Negara dan Usaha Bina-Negara di Jawa Masa Lalu, Studi tentang Masa Mataram II Abad XVI-XIX. Jakarta: Yayasan Obor Indonesia.

Rahardjo, Supratikno (ed.). 1989. Kota Dagang Cirebon sebagai Bandar Jalur Sutera. Jakarta: Departemen Pendidikan dan Kebudayaan Republik Indonesia.

Ricklefs, Merle Calvin. 2010. Sejarah Indonesia Modern 1200-2004. Jakarta: Serambi.

Soemardjan, Selo. 1984. "Land Reform di Indonesia", dalam Sediono M.P. Tjondronegoro dan Gunawan Winardi (peny.), Dua Abad Penguasaan Tanah, Pola Penguasaan Tanah Pertanian di Jawa dari Masa ke Masa. Jakarta: Yayasan Obor Indonesia dan Gramedia.

Stapel, Frederik Willem. 1940. Geschiedenis van Nederlandsch Indie, Batavia: 1940, Jilid V.

Tijdschrift van Binnenlandsch Bestuur 23, 1902.

Vlekke, Bernard Hubertus Maria. 1959. Nusantara: A History of Indonesia. The Hague: W. Van Hoeve. 
Tendi

Zuhdi, Susanto. 1996. "Hubungan Pelabuhan Cirebon dengan Daerah Pedalaman: Suatu Kajian dalam Kerangka Perbandingan dengan Pelabuhan Cilacap 1880-1940" dalam Susanto Zuhdi (peny.), Cirebon sebagai Bandar Jalur Sutra: Kumpulan Makalah Diskusi Ilmiah. Jakarta: Pendidikan dan Kebudayaan Republik Indonesia.

\section{LAMPIRAN}

Surat Laporan Raden Natadireja kepada Gubernur Jenderal W.H. Daendels ${ }^{22}$

${ }^{22}$ Surat ini diterjemahkan oleh Titin Nurhayati Ma'mun dan dipresentasikan dengan judul "Surat Dipati Natadireja kepada Daendels," dalam Simposium Internasional ke-16 Pernaskahan Nusantara dan Musyawarah nasional ke-6 Manassa, jakarta, 26-29 September 2016. 


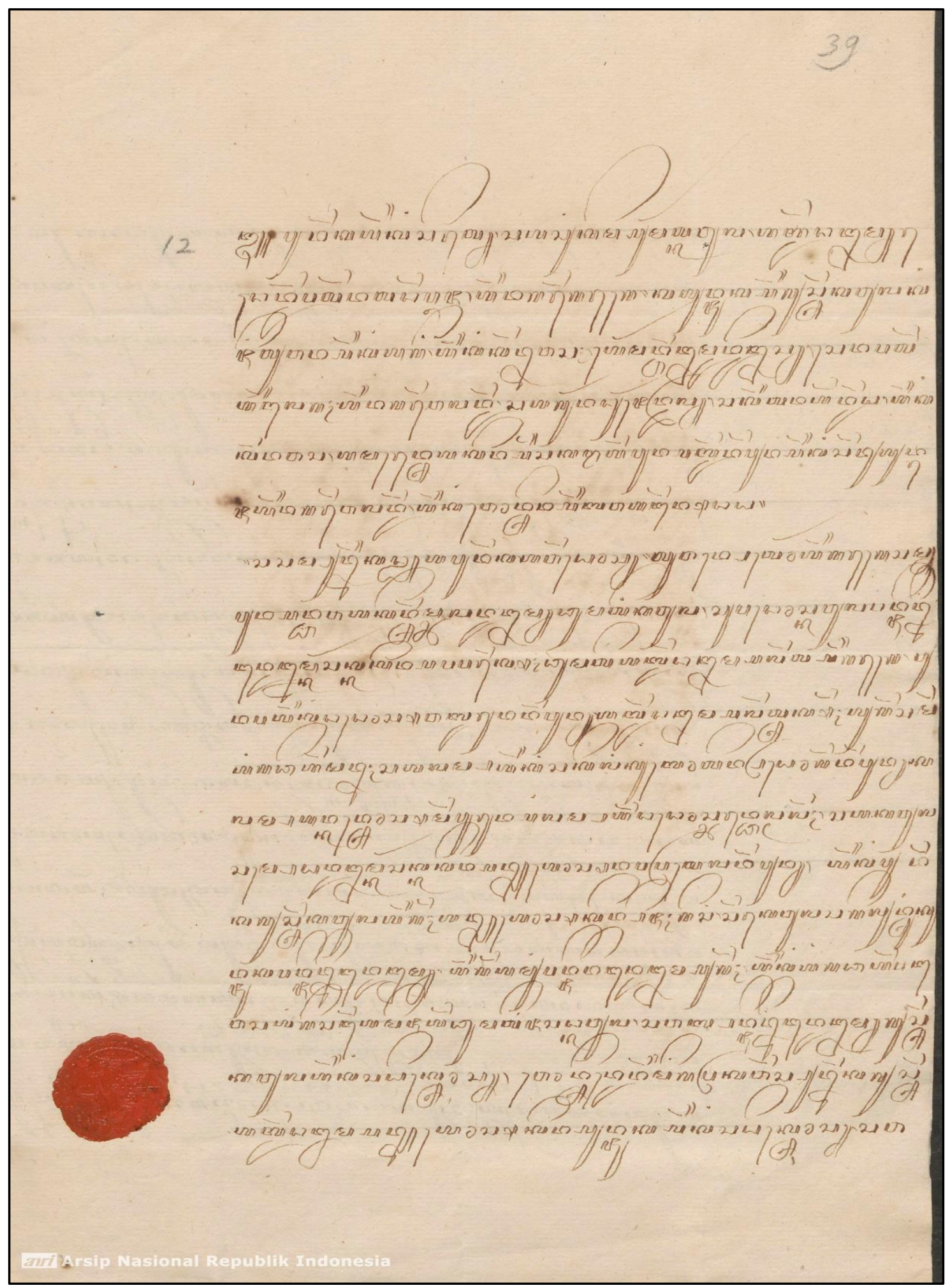




\section{Tendi}

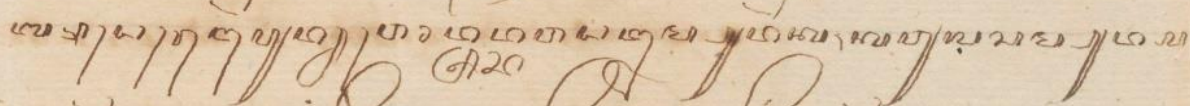
खथा

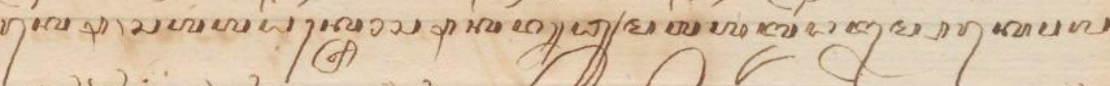

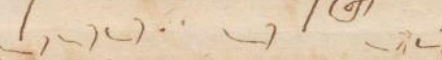

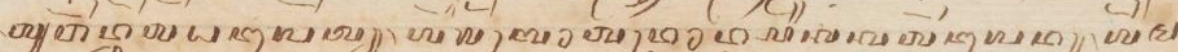
An I If $7^{2 T}$ GA

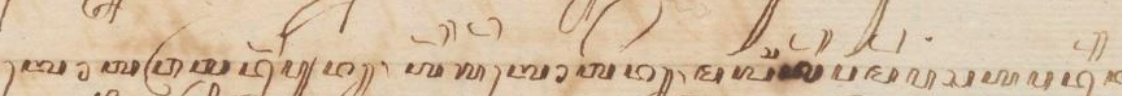

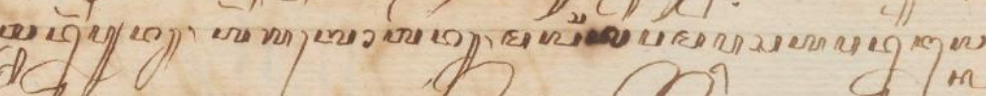
¿11 op () $)$

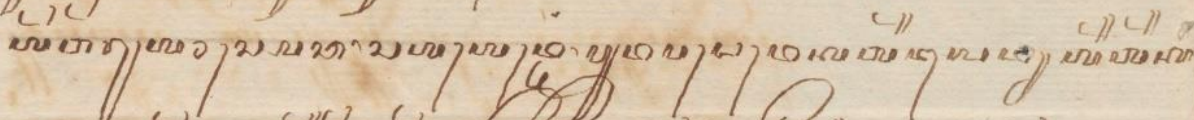
$1 \mathrm{ICH}_{4} \mathrm{Cl}$

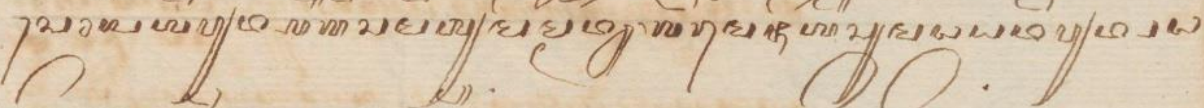

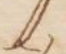

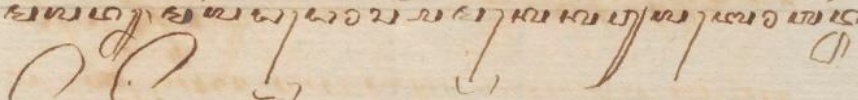

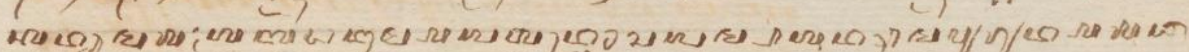
(i) $\mathrm{C}$.

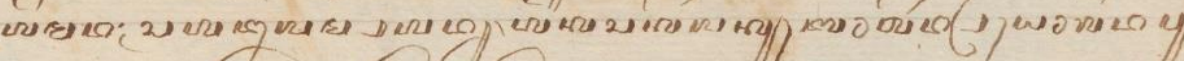
$\therefore(1)(1)$

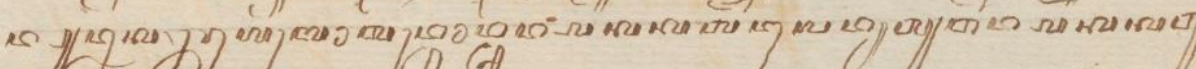
(1)

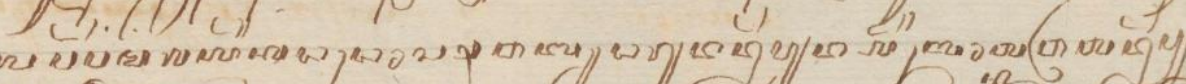

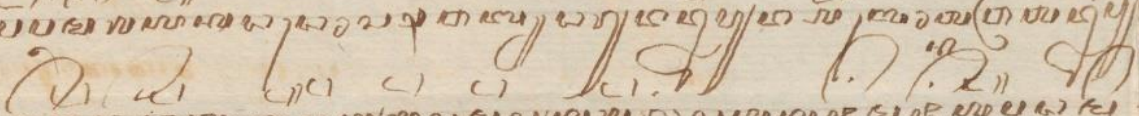

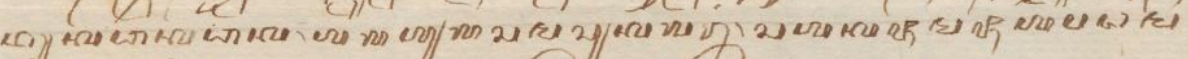

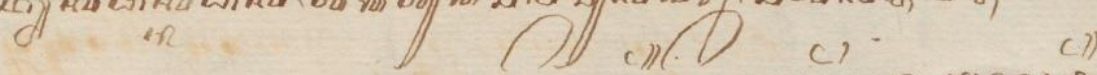
an ex)" (

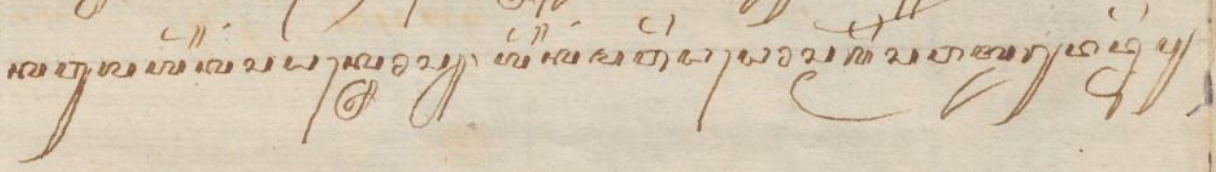




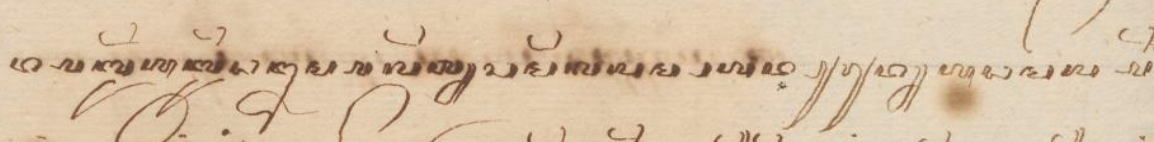

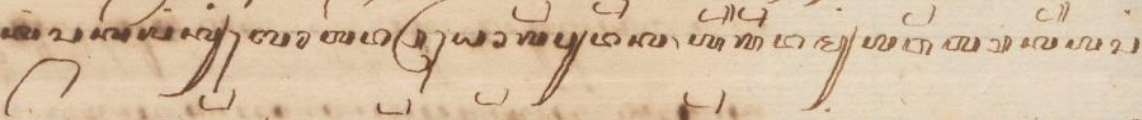

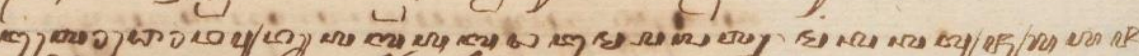
1300 C,

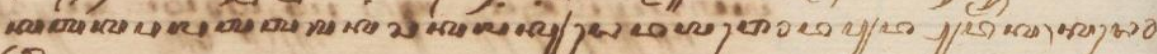
(5)

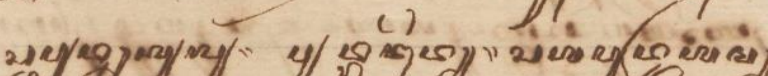

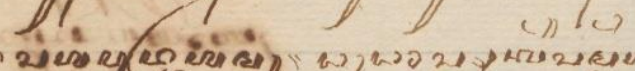

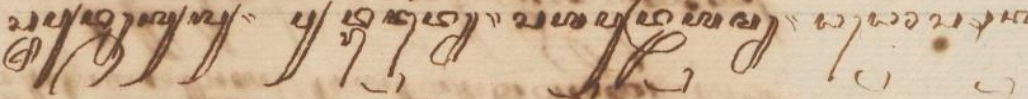

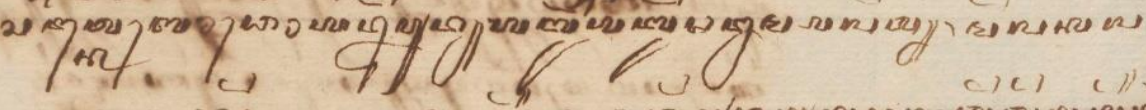

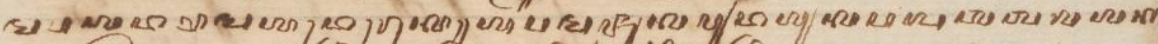

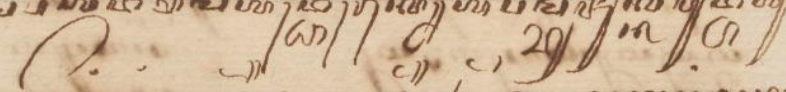

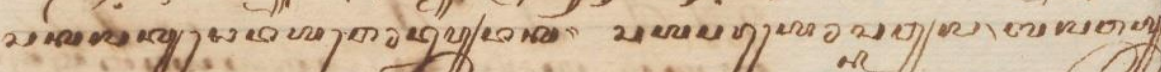
(1) (a)

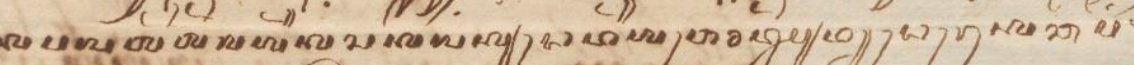
(is)

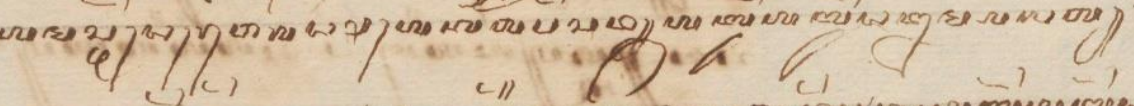

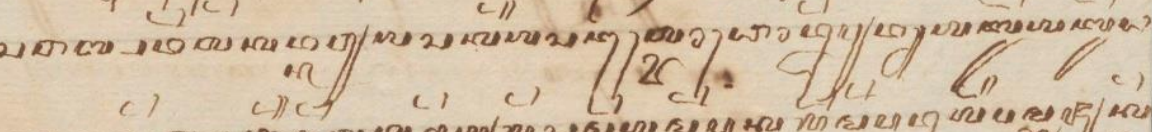

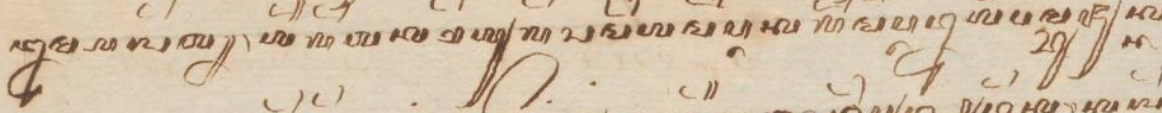

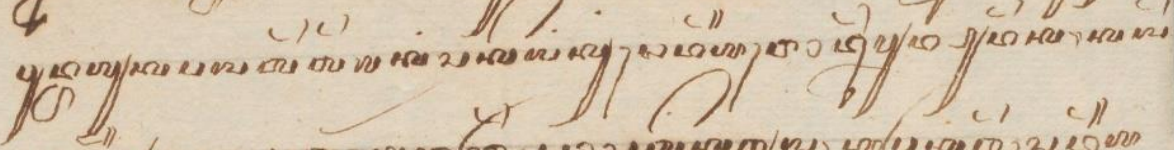

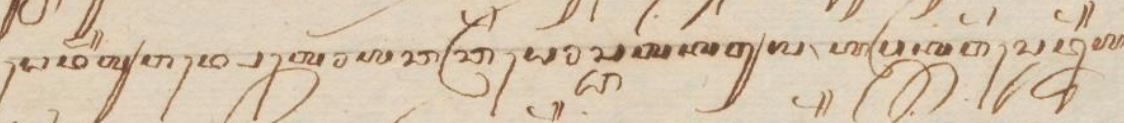

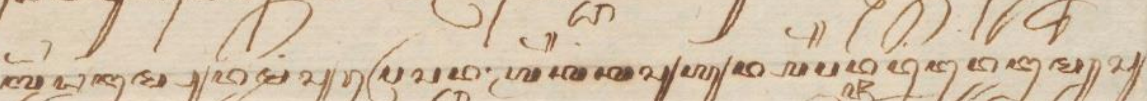
Che

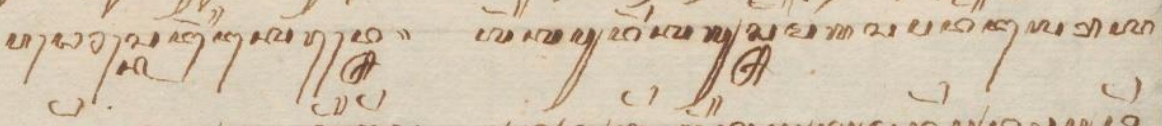

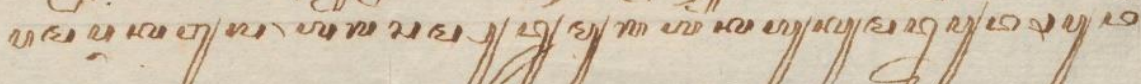


Tendi

42

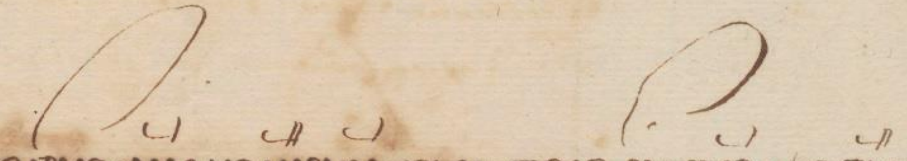

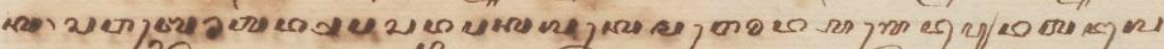
(n)

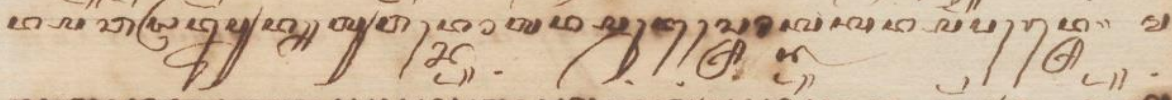

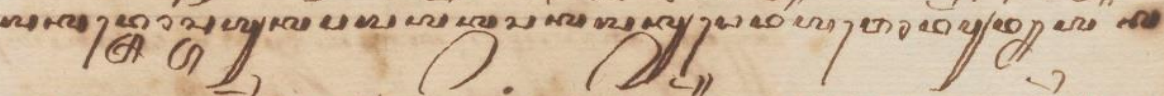

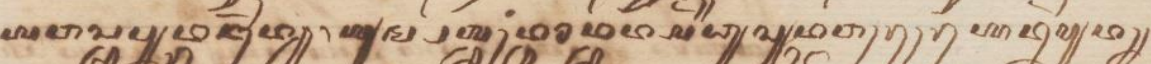

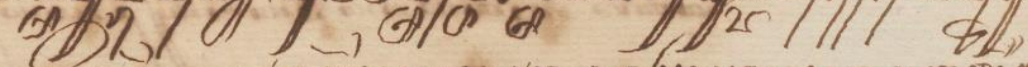

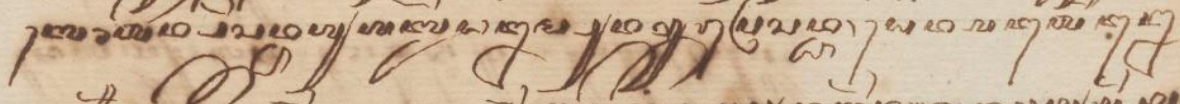

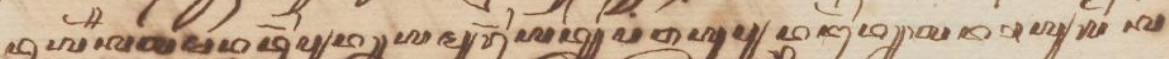
$\mathrm{G}_{1}^{2}$

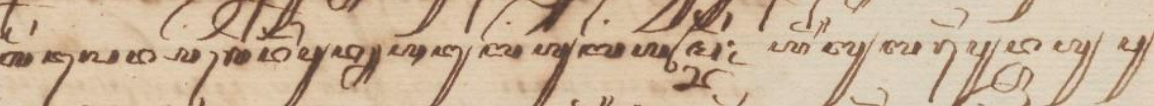
I

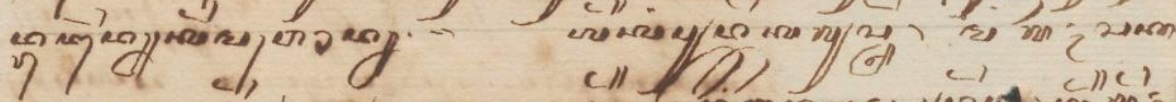

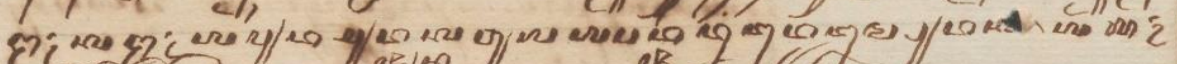

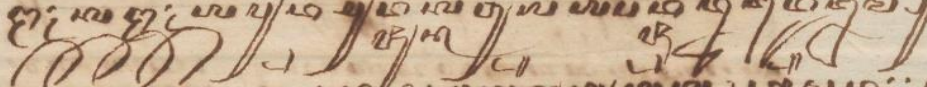

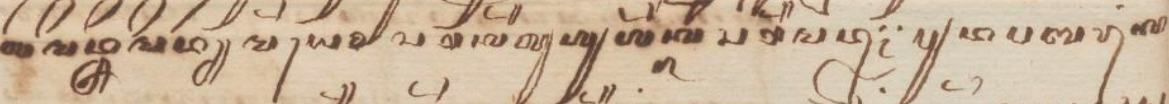

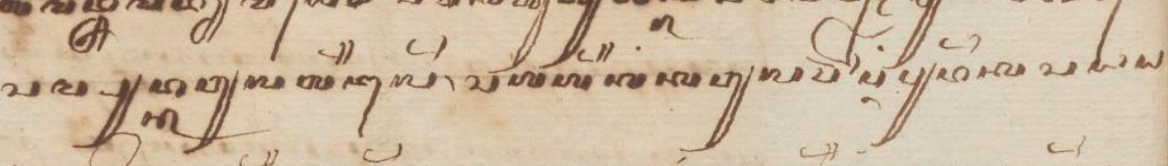

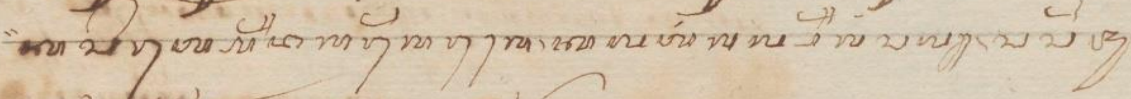

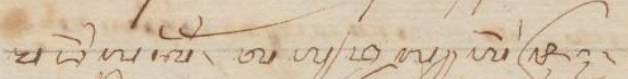

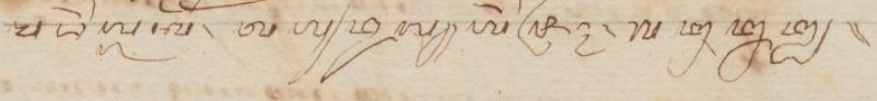




\section{TERJEMAHAN:}

Inilah surat (yang dikirim) dengan sembah sujud (serta) hormat saya, Raden Dipati Natadireja (yang bertugas) di Negeri Cirebon. Teruntuk tuan besar nan berkuasa, Herman Willem Daendels, panglima perang Negeri Belanda serta Gubernur Jenderal Hindia yang memerintah negeri-negeri bawah angin atas nama raja Belanda.

Selanjutnya (saya) beritahukan, Petor Cirebon menyampaikan kabar (bahwa) saya (dan) anda sebaiknya memeriksa (para) abdi dalem alit di Cirebon. (Hal itu harus dilakukan) lantaran para abdi dalem alit masih juga tega berbuat tidak pantas (yakni) berani ikut-ikutan menjadi pengacau (barandhal), (di mana) saya (kepada) Anda akan memberi penjelasan tentang hal itu.

Tuan, saya menyerahkan mati hidup diri saya seutuhnya kepada Anda. (Lagi pula,) memang, anda memiliki kekuasaan untuk menghidupkan (atau) mematikan jasad saya karena anda (merupakan) tuan saya yang sebenar-benarnya.

(Terkait dengan) perkara tersebut, Tuan, saya (hendak) menyampaikan kenyataan yang sebenar-benarnya karena sebelumnya saya telah memeriksa sekaligus membuktikan (dugaan yang ditujukan) terhadap para kapala serta orang-orang kecil (titiyang alit; para bawahan),

Sama sekali tidak kelihatan, dalam mata saya, dari apa yang sama-sama dimiliki, aturan yang diberlakukan, sebab apa-apa (itu), (saya pandang) sama sekali tidak memberatkan.

Berdasarkan pendengaran dan penglihatan saya yang telah dibuktikan secara sungguh-sungguh, (bahwa saat ini mereka) merasa senang, (dan merasa) mudah. Hal itu terlihat dalam perilaku yang secara nyata (mereka tunjukkan), (yakni) bergembira hati dalam melakukan semua pekerjaan. Oleh karena itu, saya sama sekali tidak merasakan bahwa para abdi dalem alit telah melakukan perbuatan yang tidak pantas tersebut.

Soalnya, itu tadi, (saya) sama sekali tidak pernah melihat dan mendengar sedikit pun tentang keberatan (keluhan) mereka. (Sebaliknya, mereka) sangat senang dalam melakukan pekerjaan.

(Meskipun demikian, dalam kesempatan ini), sesungguhnya, saya menyimpan kekhawatiran bahwa para abdi alem alit memang telah berani memperbuat sesuatu yang tidak pantas.

Sebenarnya hal itu bermula dari kebodohan para abdi dalem alit sehingga terbujuk untuk mengikuti langkah kapala titiga yang sesungguhnya sangat buruk, 
seperti Kulur, Rangin, serta Draham. Kebodohan itulah yang membuat para abdi dalem alit termakan bujuk rayu kapala titiga untuk melakukan perbuatan yang sangat buruk tersebut.

Serta kekhawatiran saya, selagi kapala titiga yang sangat buruk itu belum tertangkap, mesti belum datang ketenteraman kepada diri para abdi dalem alit, meskipun masih juga mendengar tentang bujuk rayu kapala titiga yang berkelakuan buruk tersebut.

Selain itu, Petor Cirebon juga membicarakan dengan abdi dalem yang bernama Demang Suraprasandhah yang diminta oleh Anda untuk mendapat hukuman (akarante). Soal ini, berdasarkan penglihatan dan pendengaran saya, sebenarnya hukuman tersebut sudah diberlakukan. Soalnya, tak hanya sekali dua kali ia memperlihatkan pembangkangan (cidhranipun) serta tidak mengindahkan perintah.

Malah, salah seorang dari kapala titiga, bernama Rangin, (pernah) bersembunyi di sebuah dusun yang berada di wilayah kekuasaan Demang Suraprasandhah. Jelas-jelas ia kedapatan tidak ingin menangkap Rangin. Sebaliknya, ia justru menyuruh Rangin untuk melarikan diri.

Inilah, Gusti, hal-hal yang bisa saya sampaikan dengan sebenar-benarnya. Saya pun melaporkan hal ini dengan tulus ikhlas dari hati, tentang segala hal yang saya lihat dan dengar.

Ditulis di Negeri Cirebon, pada tanggal 5 Jumadilakhir Tahun Dal 122 Hijriah. 
